\title{
ДОСЛІДЖЕННЯ ПРОЦЕСІВ УТИЛІЗАЦІї ТЕПЛА ПАРОПОВІТРЯНИХ СУМІШЕЙ: РЕЗУЛЬТАТИ ЕКСПЕРИМЕНТІВ, СТРУКТУРНА ТА ПАРАМЕТРИЧНА ІДЕНТИФІКАЦІЯ ОСНОВНИХ КАНАЛІВ ОБ'ЄКТУ
}

\author{
Ковальчук Д.А. ${ }^{1}$, Мазур О.В. ${ }^{2}$, Хобін В.А. ${ }^{3}$ \\ 1,2,3 Одеська Національна Академія харчових технологій \\ ${ }^{1}$ Аспірант, ${ }^{2}$ Доцент, к.т.н., ${ }^{3}$ Професор, д.т.н. \\ ORCID: ${ }^{1}$ http://orcid.org/0000-0003-0549-5244, ${ }^{2}$ http://orcid.org/0000-0001-7104-9010, ${ }^{3}$ http://orcid.org/0000-0003-0238- \\ 8371 \\ E-mail: ${ }^{1}$ radiolomaster@gmail.com, ${ }^{2}$ mazur.av.ua@gmail.com, ${ }^{3}$ khobin@onaft.edu.ua
}

Copyright $(2018$ by author and the journal "Automation technologies and business - processes.

This work is licensed under the Creative Commons Attribution International License (CC BY).

http://creativecommons.org/licanses/by/4.0

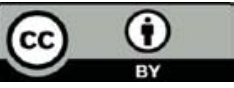

ONAFT

Open Access

DOI:

Анотація: У статті розглянуто актуальність і необхідність застосування систем, щзо дозволяють утилізувати тепло пароповітряних сумішей як енергетичних відходів. Розглянуто різні варіанти утилізації на прикладі газових котлів, як джерела великої кількості енергетичних відходів у вигляді димових газів, виділені їх недоліки. Для більш глибокої утилізації тепла пароповітряних сумішей запропоновано можливість застосування теплового насоса, а також удосконалення системи автоматичного керування процесом утилізації тепла димових газів з тепловим насосом у складі, для подальшого підвищення енергетичної ефективності. Представлена параметризована схема технологічного процесу утилізації тепла димових газів. Наведені результати експериментів, по дослідженню процесу утилізації в автоматичному режимі на фізичній моделі, розробленій авторами. Проведено аналіз результатів. Виконана структурна ідентифікація процесу утилізації тепла димових газів як об'єкту керування, виділені основні канали керування, перехресні зв'язки між ними, та найбільш впливові збурення. Складено параметричну схему процесу як об'єкту керування. Проведено параметричну ідентифікацію основних каналів керування, перехресних зв'язків та контрольованих збурень в ході якої отримані математичні моделі основних каналів перетворення координатних дій.

Annotation: The article considers the urgency and necessity of using systems that allow to utilize the heat of steam-air mixtures as energy wastes. Different variants of utilization on the example of gas boilers as sources of a large amount of energy waste in the form of flue gases are considered, their drawbacks are highlighted. For a more profound utilization of the steam-air mixtures heat, the possibility of using a heat pump, as well as improving the system of automatic control of the process of utilization of the flue gases heat with a heat pump in the composition, is proposed for further increase of energy efficiency. A parametrized scheme of the process of flue gas heat recovery is presented. The results of experiments, on the study of the utilization process in the automatic mode on the physical model, developed by the authors are presented. The analysis of results is carried out. The structural identification of the process of utilization of heat of flue gases as a control object is carried out, the main control channels, cross-links between them, and the most influential perturbations are allocated. A structural scheme of the process is created as an control object. The parametric identification of the main control channels, cross-links and controlled disturbances was carried out, during which mathematical models of the main channels for transformation of coordinate actions were obtained.

Ключові слова: дослідження, тепловий насос, утилізація тепла, статичні характеристики, динамічні характеристики

Вступ

Постійне зростання цін на енергоносії все більш загострює питання енергозбереження. В умовах конкуренції підприємства змушені оптимізувати собівартість продукції, яка включає і витрати енергії на іiї випуск. 
Одним з заходів, що дозволяє знизити енергетичні витрати на ведення технологічного процесу, є вдосконалення алгоритмів керування. Це особливо актуально у випадку, коли технологічний процес ведеться в декількох технологічних агрегатах, на функціонування кожного з яких накладені специфічні обмеження, а найбільш ефективні режими їх роботи вступають у протиріччя з цими обмеженнями.

\section{1. Огляд літературних джерел}

У $[1,2]$ було розглянуто тепловий потенціал пароповітряних сумішей, які уявляють собою енергетичні відходи технологічних процесів та актуальність застосування систем утилізації їх тепла. Це дозволяє зменшити енергетичні витрати на ведення технологічного процесу та знизити собівартість готової продукції. Подальше підвищення енергетичної ефективності технологічного процесу можливе за рахунок створення інноваційних систем утилізації тепла ППС, а також за рахунок розробки нових алгоритмів керування.

Значну кількість енергетичних відходів утворює теплогенеруюче обладнання на базі газових котлів. Аналіз основних енергетичних втрат при роботі газового котла проводився у $[3,4]$. Найбільш суттєвими є втрати 3 димовими газами, які можуть складати до $15 \%$ [3].

Різноманітні системи утилізації тепла димових газів, поширені у промисловості, розглянуто та досліджено у багатьох джерелах, зокрема у $[4,5,6,8]$. Зазвичай вони полягають у встановленні на димоході котла спеціальних теплообмінників, які забезпечують охолодження димових газів та нагрів теплоносія з низьким температурним потенціалом. У $[9,10]$ проводиться огляд різних конструкцій контактних та безконтактних утилізаторів тепла димових газів, які використовуються на газових котельнях. Для отримання максимально можливої кількості теплової енергії необхідно охолодити димові гази суттєво нижче точки конденсації водяного пару, що входить до їх складу. Саме при конденсації водяних парів виділяється найбільша кількість теплової енергії [7]. Точка роси димових газів, тобто початок конденсації водяного пару, в залежності від співвідношення газ/повітря, може змінюватись в діапазоні від 40 до $58 \mathrm{C}[7,11]$. Глибина утилізації тепла димових газів буде залежати від того, наскільки вони переохолоджені відносно точки роси. При переохолоджені на кожні 10 С буде утилізовано приблизно 30\% енергії пари в ППС.

Для всіх цих засобів існує загальна проблема - для максимальної утилізації тепла потрібно мати навантаження у вигляді споживача теплової енергії з низьким температурним потенціалом (від 10 до $\left.30{ }^{\circ} \mathrm{C}\right)$. В деяких технологічних процесах таке навантаження існує. Наприклад, при роботі парового котла 3 постійною витратою пари та необхідністю підживлення водою можлива утилізація тепла ДГ за рахунок підігріву живлячої води. При роботі котла на систему гарячого водопостачання можлива утилізація за рахунок попереднього підігріву води. Утилізація також можлива за рахунок підігріву зворотного теплоносія при роботі котла у низькотемпературній системі опалення, наприклад «тепла підлога». В інших випадках, коли низькотемпературне навантаження не доступне, реалізувати глибоку утилізацію теплову енергію димових газів проблематично. Заявлені виробниками високі показники енергетичної ефективності розповсюджених останнім часом газових котлів з вбудованою секцією конденсації (конденсаційних котлів) також підтверджуються тільки при роботі на низькотемпературне навантаження при температурах зворотної води $20-35{ }^{\circ} \mathrm{C}$.

У $[3,7]$ проводились дослідження режимів роботи системи опалення багатоповерхового будинку, яка являє собою типове теплове навантаження для системи утилізації тепла. Дослідження показали, що температура теплоносія в зворотному трубопроводі системи опалення, яка по суті є температурою води на вході конденсатора ТН, у продовж опалювального сезону змінюється в залежності від температури навколишнього середовища в широкому діапазоні (від 30 до $50{ }^{\circ} \mathrm{C}$ ). Тому одним 3 можливих рішень побудови системи глибокої утилізації тепла ДГ є застосування теплового насосу $[7,12]$. Це дозволяє знизити температуру охолодження ППС і підняти температурний потенціал отриманої теплової енергії, що суттєво збільшує кількість варіантів можливого ії̈ застосування та дозволяє підвищити ефективність системи утилізації в цілому. При зниженні температури охолодження димових газів, глибина утилізації теплової енергії росте, однак при цьому і зростають питомі витрати енергії на роботу теплового насосу і знижується енергетична ефективність системи утилізації в цілому. В роботах $[4,5,6]$ були проведені дослідження по визначенню оптимальних температур охолодження димових газів в залежності від температури їх точки роси. В залежності від складу газу та співвідношення газ-повітря на вході котла точка роси може змінюватись в діапазоні від 48 до $58{ }^{\circ} \mathrm{C}$. При цьому оптимальна, з огляду на мінімальні питомі енергетичні втрати, температура охолодження димових газів (ДГ) змінюється відповідно від 30 до $35^{\circ} \mathrm{C}$. Для забезпечення таких режимів, навіть при застосуванні контактного теплоутилізатора, температура води на його вході повинна підтримуватись в діапазоні від 20 до $25^{\circ} \mathrm{C}$ відповідно.

Для дослідження процесів утилізації тепла ППС з використанням теплових насосів авторами було створено фізичну модель тепловою потужністю до 8 кВт, яка складається 3 генератора ППС з заданими параметрами (температурою, вологістю та витратами), утилізатора тепла на базі контактного теплообмінника та теплового насосу. Фізична модель оснащена мікропроцесорною системою збору даних та управління. Детальний опис фізичної моделі приведено у [13].

Підвищення енергетичної ефективності та надійності системи глибокої утилізації ДГ з використанням теплового насосу можливе за рахунок розробки та впровадження вдосконалених алгоритмів керування. Цей етап потребує великої кількості попередніх досліджень. Із застосуванням фізичної моделі було проведено ряд експериментів 3 дослідження процесу утилізації тепла ППС як об'єкту керування (ОК). Фізична модель дозволяє проводити 
експерименти у автоматичному режимі, що суттєво скорочує час на проведення досліджень. Саме завдяки цьому отримані квазістатичні та динамічні характеристики по різним каналам, аналіз яких дозволяє розробити концепцію побудови енегргоефективної системи автоматичного управління. Фізична модель дозволяє проводити випробування розроблених алгоритмів керування в квазіреальних умовах роботи.

\section{2. Експериментальні дослідження}

Параметризована схема процесу глибокої утилізації тепла ДГ з використанням теплового насосу представлена на рисунку 1.

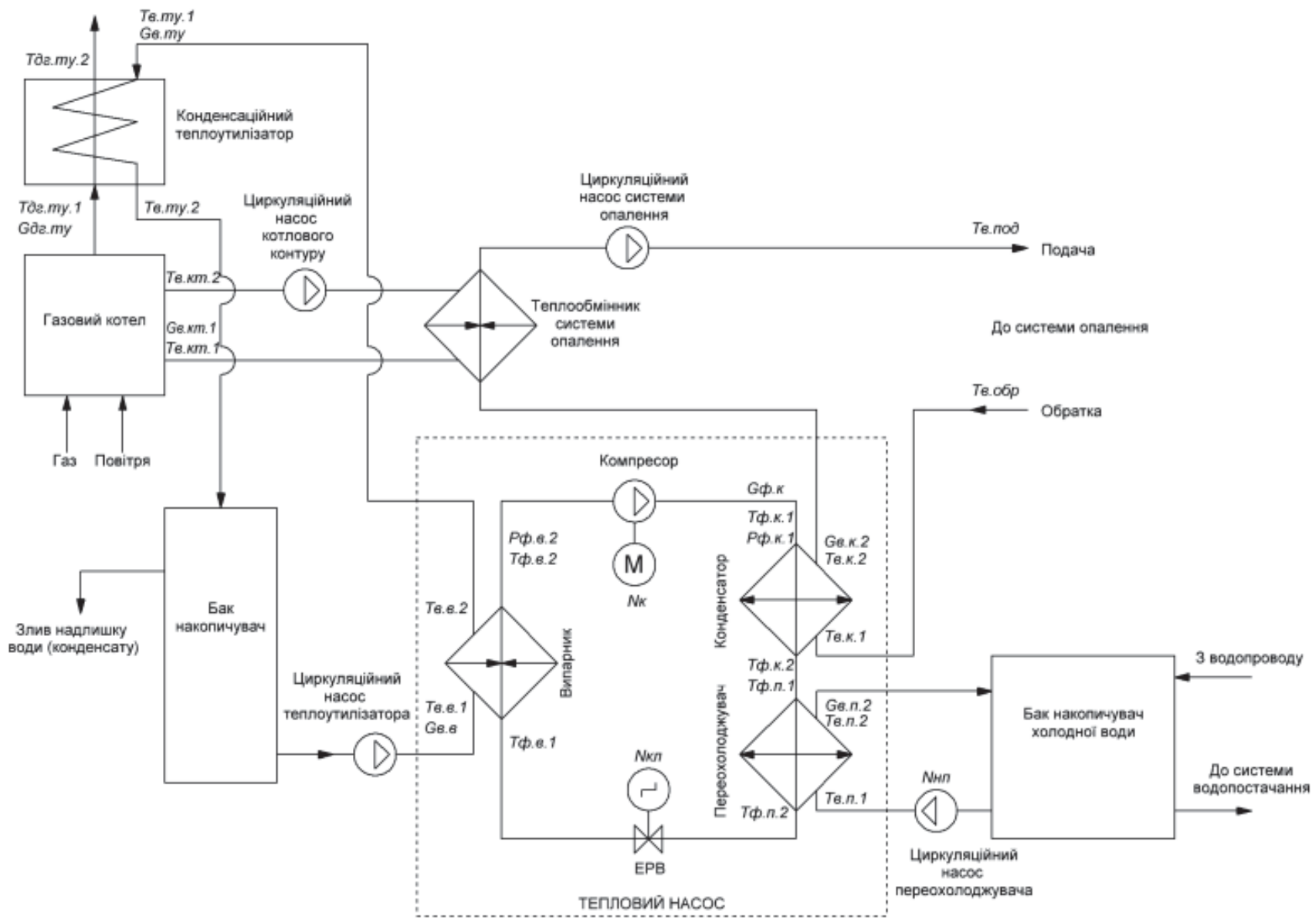

Рис. 1 - Параметризована схема процесу глибокої утилізації тепла ДГ з використанням теплового насосу

Перелік змінних параметризованої технологічної схеми та отримані в результаті аналізу літературних джерел очікувані діапазони їх змін перераховані нижче.

$\mathrm{T}_{\text {дг.ту.1 }}$ - температура димових газів на вході у конденсатор димових газів, $\mathrm{T}_{\text {дг.ту. } 1} \in\left[100 \ldots 150^{\circ} \mathrm{C}\right]$;

$\mathrm{T}_{\text {дг.ту.2 }}$ - температура димових газів на виході теплоутилізатора, $\mathrm{T}_{\text {дг.ту.2 }}\left[20 \ldots 40^{\circ} \mathrm{C}\right]$;

$\mathrm{G}_{\text {дг.ту }}$ - витрати димових газів, $\mathrm{G}_{\text {дг.ту }} \in\left[50 \ldots 100 \mathrm{~m}^{3} /\right.$ год];

$\mathrm{P}_{\text {ф.в. }}-$ тиск фреону на виході випарника, $\mathrm{P}_{\phi . в} \in[2 \ldots 6$ атм];

$\mathrm{P}_{\phi . к}-$ тиск фреону у конденсаторі, $\mathrm{P}_{\phi . к} \in[10 \ldots 20$ атм $]$;

$\mathrm{G}_{\text {ф.к }}-$ витрати фреону;

$\mathrm{T}_{\text {ф.в.1 }}-$ температура фреону на вході випарника, $\mathrm{T}_{\text {ф.в.1 }} \in\left[0 \ldots 15^{\circ} \mathrm{C}\right]$;

$\mathrm{T}_{\text {ф.в.2 }}-$ температура фреону на виході випарника, $\mathrm{T}_{\text {ф.в. }} \in\left[0 \ldots 15^{\circ} \mathrm{C}\right]$;

$\mathrm{T}_{\text {ф.к.1 }}$ - температура фреону на вході конденсатора, $\mathrm{T}_{\text {ф.к. } 1} \in\left[30 \ldots 50^{\circ} \mathrm{C}\right]$;

$\mathrm{T}_{\text {ф.к.2 }}$ - температура фреону на виході конденсатора, $\mathrm{T}_{\text {ф.к. }} \in\left[30 \ldots 50^{\circ} \mathrm{C}\right]$;

$\mathrm{T}_{\text {ф.п. } 1}$ - температура фреону на вході переохолоджувача;

$\mathrm{T}_{\text {ф.п. }}-$ температура фреону на виході переохолоджувача; 
$\mathrm{T}_{\text {в.в.1 }}-$ температура води на вході у випарник, $\mathrm{T}_{\text {в.в.1 }} \in\left[30 \ldots 50^{\circ} \mathrm{C}\right]$;

$\mathrm{T}_{\text {в.в.2 }}$ - температура води на виході з випарника, $\mathrm{T}_{\text {в.в.2 }} \in\left[10 \ldots 30^{\circ} \mathrm{C}\right]$;

$\mathrm{G}_{\text {в.в }}$ - витрати води крізь випарник, $\mathrm{G}_{\text {в.в }} \in\left[5 \ldots 15 \mathrm{~m}^{3} /\right.$ год];

$\mathrm{T}_{\text {в.к.1 }}-$ температура води на вході в конденсатор, $\mathrm{T}_{\text {в.к.1 }} \in\left[20 \ldots 50^{\circ} \mathrm{C}\right]$;

$\mathrm{T}_{\text {в.к.2 }}-$ температура води на виході конденсатора, $\mathrm{T}_{\text {в.к.2 }} \in\left[20 \ldots 50^{\circ} \mathrm{C}\right]$;

$\mathrm{G}_{\text {в.к }}$ - витрати води крізь конденсатор, $\mathrm{G}_{\text {в.к }} \in\left[5 \ldots 15 \mathrm{~m}^{3} /\right.$ год];

$\mathrm{T}_{\text {в.п.1 }}-$ температура води на вході переохолоджувача;

$\mathrm{T}_{\text {в.п.2 }}$ - температура води на виході переохолоджувача;

Gв.п - витрати води крізь переохолоджувач;

Nк- обороти компресора;

$\mathrm{N}_{\text {кл }}$ - положення розширювального вентиля із кроковим двигуном.

Експериментальні дослідження процесу глибокої утилізації тепла димових газів (УТДГ) 3 використанням теплового насосу на базі розробленої фізичній моделі проводились у три етапи:

1. дослідження контактного теплоутилізатора як ОК;

2. дослідження теплового насосу як ОК;

3. дослідження системи глибокої УТДГ в цілому як ОК.

\section{1. Дослідження контактного теплоутилізатора як ОК}

В роботах $[6,8,9]$ показано, що, в залежності від параметрів теплового насосу та коефіцієнту надлишку повітря, найбільш вигідна 3 енергетичної точки зору глибина утилізації тепла димових газів досягається при їх охолодженні до температури 30-35 С. Отже регулювання цієї температури є актуальною задачею.

Температурний режим димових газів на виході утилізатора Tдг.mу.2 можливо підтримувати або за рахунок цілеспрямованої зміни витрат охолоджуючої води через нього Gr.my, або за рахунок зміни температури води на вході в теплоутилізатор Tв.my.1. Технічна реалізація обох засобів не є складною. Вибір між ними повинен грунтуватись на доцільності з точки зору якості керування та енергетичної ефективності установки в цілому. Для цього були проведені експериментальні дослідження і отримані статичні залежності температури ДГна виході теплоутилізатора Tдг.my.2 та його теплової потужності від витрат теплоносія через теплоутилізатор Gв.my, та від його температури Tв.my.1. Отримані залежності показані на рисунках 2-5.

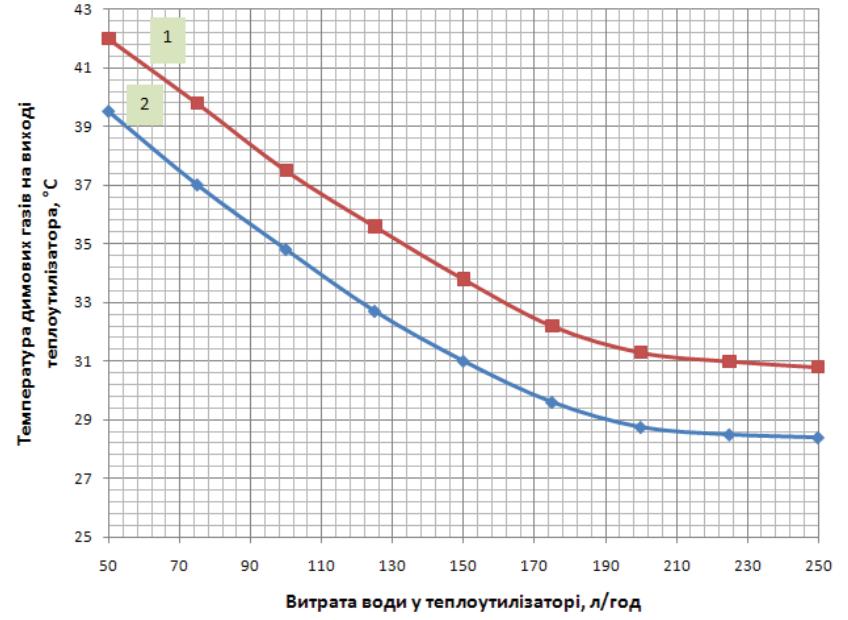

a)

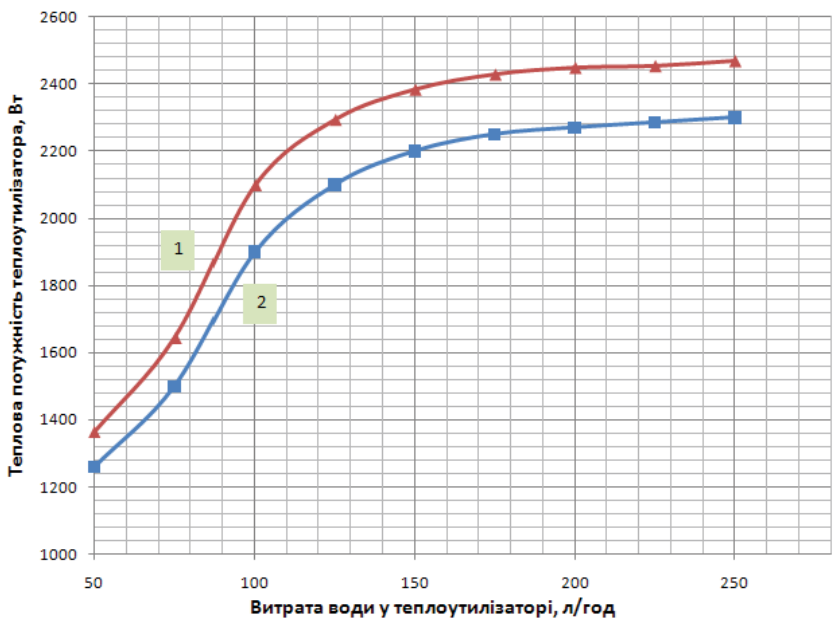

б)

Рис. 2 - Статичні характеристики ТУ при зміні витрат охолоджуючої води

На рисунках 2а та 26 наведені залежності теплової потужності ТУ та температури ДГ на виході ТУ Тдг.ту.2, відповідно від витрат води крізь ТУ при сталих температурах води на вході ТУ $\left(1-20{ }^{\circ} \mathrm{C}, 2-25^{\circ} \mathrm{C}\right)$.

На рисунку За наведено сімейство статичних характеристик по каналу «Температура води на вході ТУ температура димових газів на виході ТУ» при сталих витратах води крізь ТУ (1 - 150 л/год, 2 - 180 л/год, 3 - 230 л/год).

На рисунку $3 б$ наведені залежності теплової потужності ТУ від температура води на вході ТУ при сталих витратах води крізь ТУ (1 - 230 л/год, 2 - 180 л/год, 3 - 150 л/год). 




a)

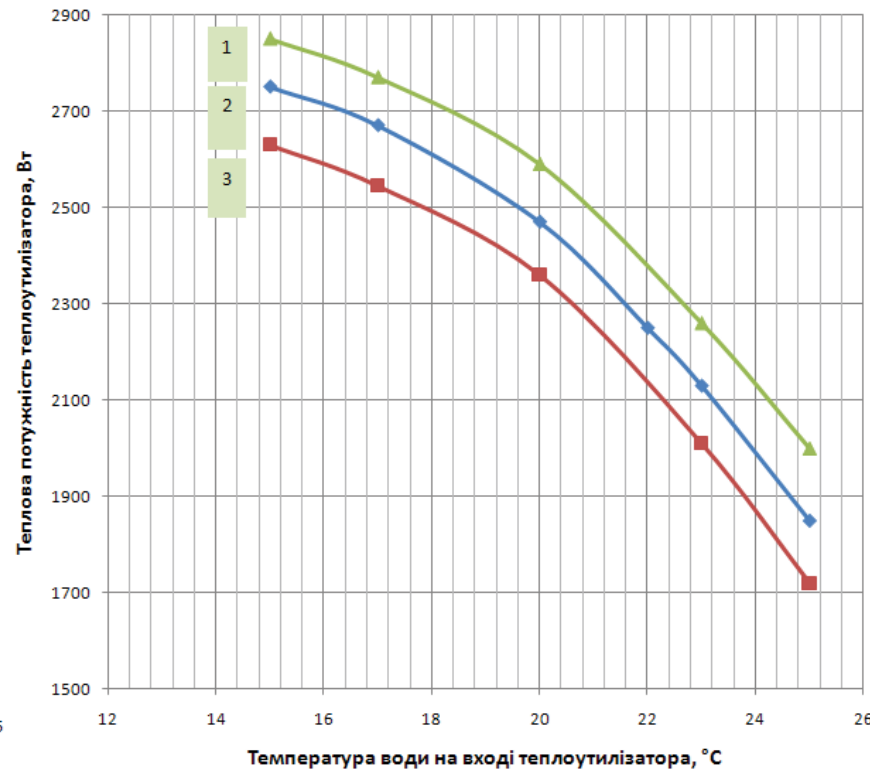

б)

Рис. 3 - Статичні характеристики ТУ при зміні температури охолоджуючої води

3 енергетичної точки зору більш вигідно підтримувати максимально можливу температуру охолоджуючої води, тому стабілізацію режиму утилізації, тобто підтримку сталої температури на виході ТУ доцільно здійснювати за рахунок зміни температури води на вході ТУ при сталих витратах води. Крім того, з результатів експериментів видно, що статичні характеристики каналу «Витрати води у ТУ - температура димових газів на виході ТУ» мають більшу нелінійність та досить невеликий робочий діапазон витрат крізь ТУ (при збільшенні витрат вище 180 л/год теплова потужність ТУ майже не змінюється).

Виходячи з цього, на рис. 4 представлена параметрична схема теплоутилізатора як об’єкта керування.

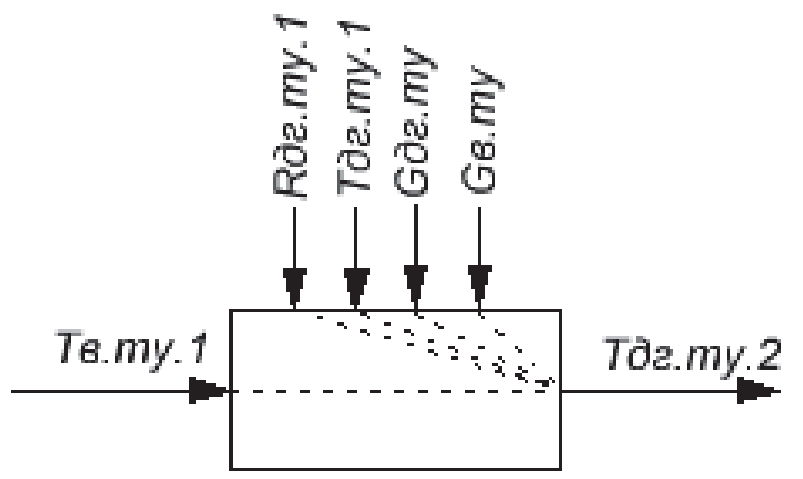

Рис. 4 - Параметрична схема теплоутилізатора як ОК

Регульованою змінною процесу є температура димових газів на виході ТУ (Tдг.my.2), а керуючим впливом температура води на вході ТУ (Tв.my.1). Всі інші параметри, які можуть впливати на температуру димових газів на виході ТУ, такі як температура (Tд2.my.1), витрати (Gdz.my) і точка роси (Rdz.my.1) димових газів на вході ТУ, та витрати охолоджуючої води крізь ТУ (Gr.my), можно віднести до неконтрольованих збурень. 3 огляду характеристик наведених на рис. 1, доцільні витрати охолоджуючої води крізь ТУ становлять близько 230 л/год., тому крива №3 на рис. 3 і буде статичною характеристикою каналу керування «Tв.my.1- Tдг.my.2»

\section{2. Дослідження теплового насосу як ОК}

На рис. 5 наведено параметричну схему ТН як ОК. 


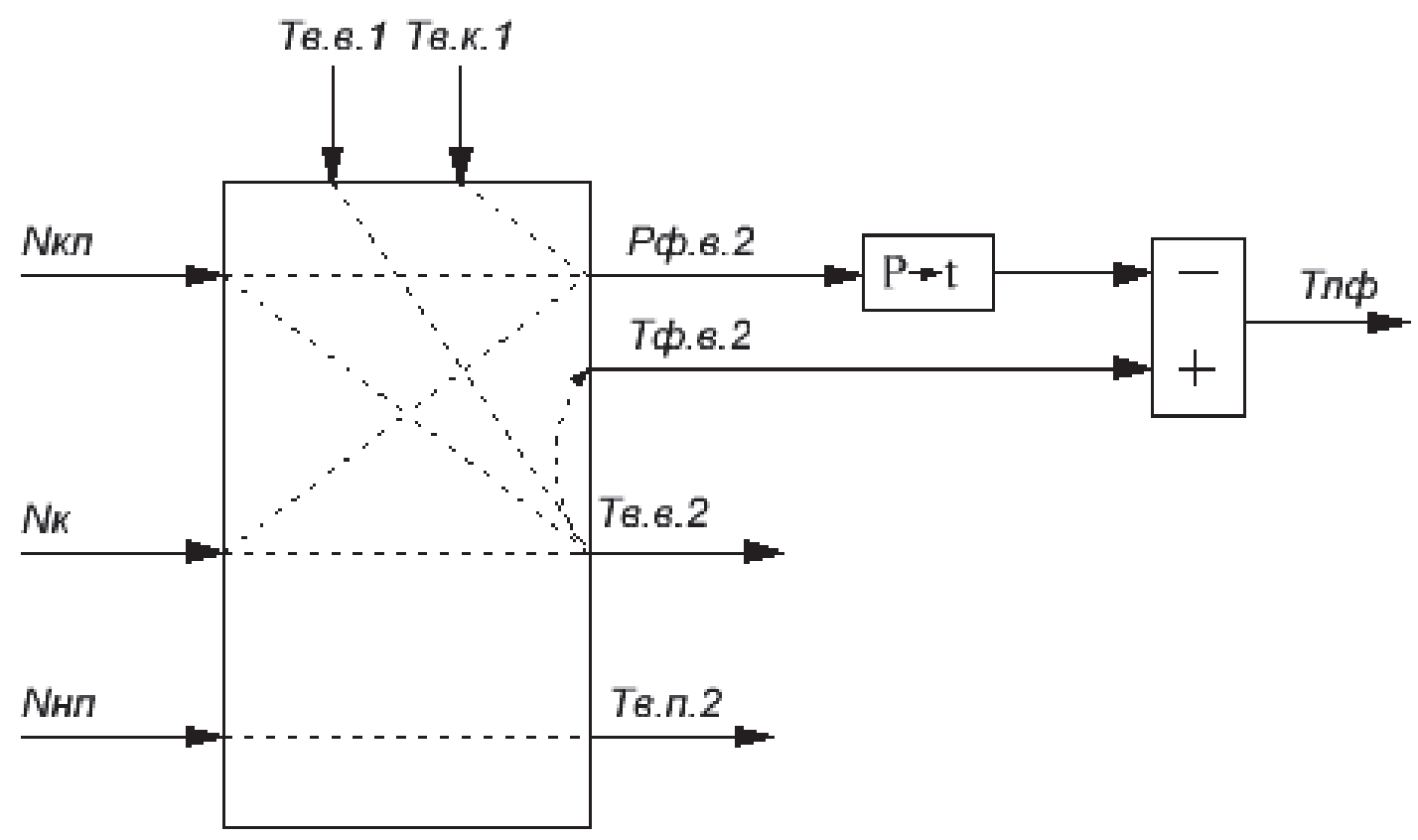

Рис. 5 - Параметрична схема ТН як ОК

Аналіз літературних джерел $[8,9,17]$ показує, що для забезпечення нормальної роботи ТН в системі управління ним повинні бути присутні мінімум 2 контури керування:

1. Контур керування температурою перегріву парів холодоагенту на виході випарника (Тпф) Він забезпечує, 3 одного боку, відсутність в складі холодоагенту на вході в компресор крапельної фази, а з іншого боку - максимально можливе завантаження випарника. При цьому величина перегріву вираховується як різниця між температурою парів холодоагенту на виході випарника (Тф.в.2) та кінцевою температурою кипіння холодоагенту (Тк.ф.в.), вирахуваною по рівню тиску парів холодоагенту на виході випарника (Рф.в). Керуючим впливом за звичай є ступінь відкриття електронного розширювального вентиля (ЕРВ). В випадку застосування ЕРВ з кроковим електроприводом керуючою дією буде кількість кроків повороту крокового двигуна (Nкл) відносно закритого стану ЕРВ.

2. Контур керування продуктивністю ТН. Регульованою координатою контуру є температура охолоджуючої води на виході випарника (Тв.в.2). Керуючим впливом контуру є частота обертання компресора ( Nk).

Основними збурюючими змінними для цих контурів регулювання є температури води на вході випарника (Т6.6.1) та конденсатора (Тв.к.1).

Для підвищення енергетичної ефективності теплового насосу до його складу включають переохолоджувач, який максимально можливо знижує температуру рідкого фреону перед ЕРВ (Tф.n.2 (див. рис. 5)). Переохолодження здійснюється теплообмінником-переохолоджувачем за рахунок попереднього підігріву питної води, яка поступає до системи гарячого водопостачання. Регульованою змінною контуру є температура води на виході переохолоджувача (T6.n.2), що підтримується на рівні температури води, яка надходить до конденсатора (Tв.к.1). А керуючим впливом є витрати води (Gs.n) крізь переохолоджувач, що задаються за рахунок зміни частоти обертання насосу переохолоджувача $(\mathrm{Nn})$.

При дослідженні режимів роботи теплового насосу були отримані сімейства квазістатичних та динамічних характеристик теплового насоса як об'єкта керування (ОК) по основних каналах керування та контрольованих збурень.

На рис ба представлені сімейства статичних залежностей по каналу «Положення ЕРВ (Nкл) - тиск на виході випарника (Pф.в) при різних частотах обертання компресора $N k(1-N k=40$ об/сек, $2-N k=45$ об/сек, $2-N k=50$ об/сек, $4-N k=55$ об/сек, $5-N k=60$ об/сек), а на рис $6 б-$ при різних температурах води на вході конденсатора Тв.к. $1\left(1-\right.$ Тв.к. $1=40^{\circ} \mathrm{C}, 2-$ Тв.к. $1=35^{\circ} \mathrm{C}, 3-$ Тв.к. $\left.1=30^{\circ} \mathrm{C}\right)$.

На рис. 6в представлені статичні залежності по каналу «Температура води на вході конденсатора Тв.к.1 - Тиск на виході випарника Рф.в» при різних положеннях ЕРВ кл $(1-N \kappa л=500$ кроків, $2-$ кл $=450$ кроків, $3-N \kappa л=400$ кроків, $4-N \kappa л=350$ кроків).

Отримані залежності демонструють суттєвий вплив режиму роботи конденсатора (температури води на його вході Tв.к.1) та режиму роботи компресора (частота обертання $N \kappa)$ на тиск холодоагенту на виході випарника $P \not . в$. Це свідчить про наявність значного перехресного зв'язку по каналу Nкл - Pф.в і сильного збурення по каналу Тв.к. 1 $P \phi . в$, та існуючу потребу компенсувати ці впливи за рахунок вдосконалення алгоритмів керування. 


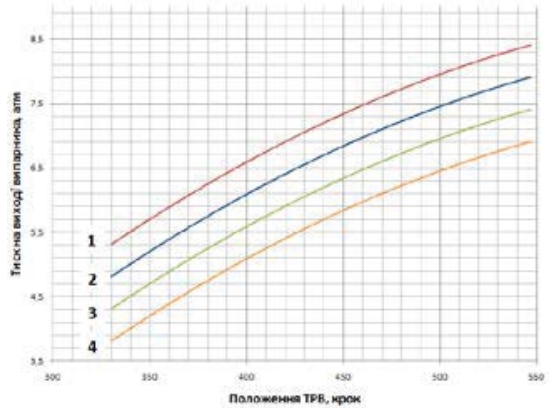

a)

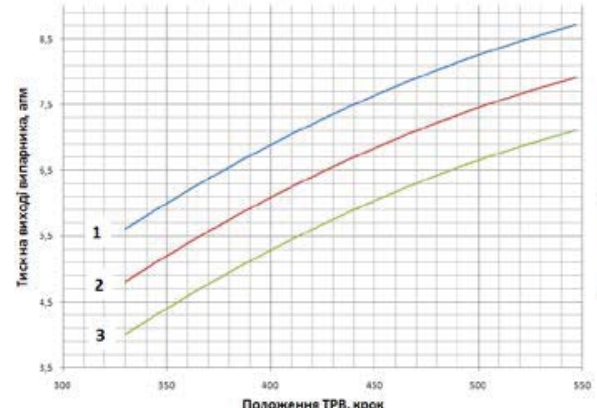

б)

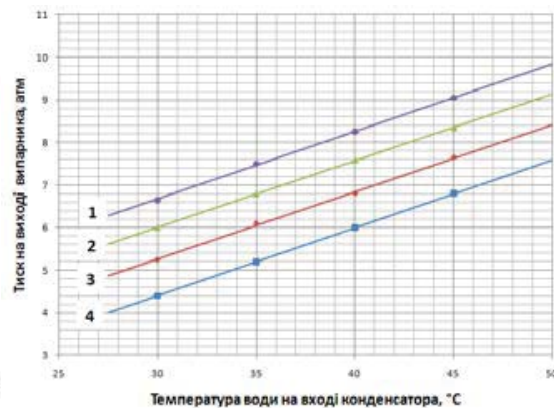

B)

Рис. 6 - Статичні характеристики ТН при зміні положення ЕРВ Nкл (а, б) та температури води на вході конденсатора Tв.к.1(в)

На рис 7а представлено сімейство статичних залежностей по каналу «Положення ЕРВ $N \kappa л-$ температура води на виході випарника Тв.в.2» при різних частотах обертання компресора $\mathrm{Nk}(1-N k=45$ об/сек, $2-N k=50$ об/сек, $3-N k$ $=55$ об/сек, $2-N k=60$ об/сек) при Тв.к. $1=35{ }^{\circ} \mathrm{C}$ та Тв.в. $1=20{ }^{\circ} \mathrm{C}$. Залежності мають лінійний характер, а вплив частоти обертання компресора - нелінійний.

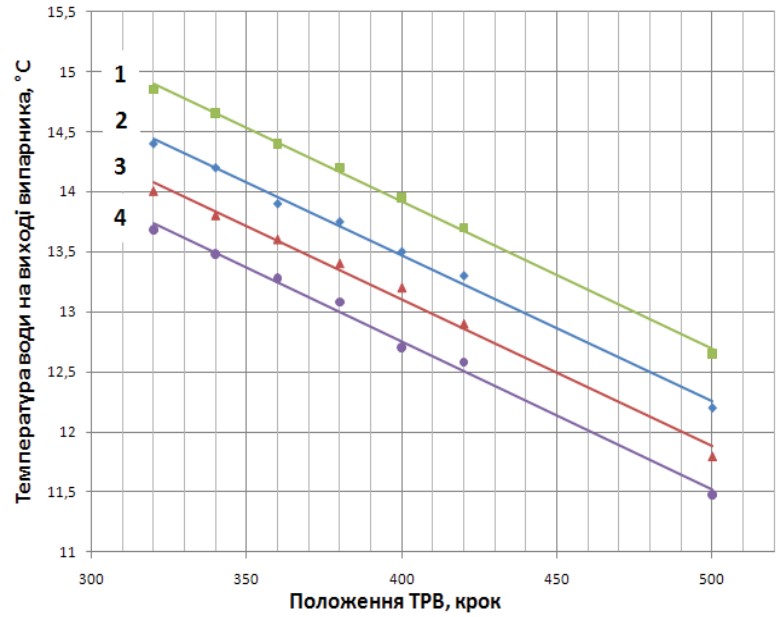

a)

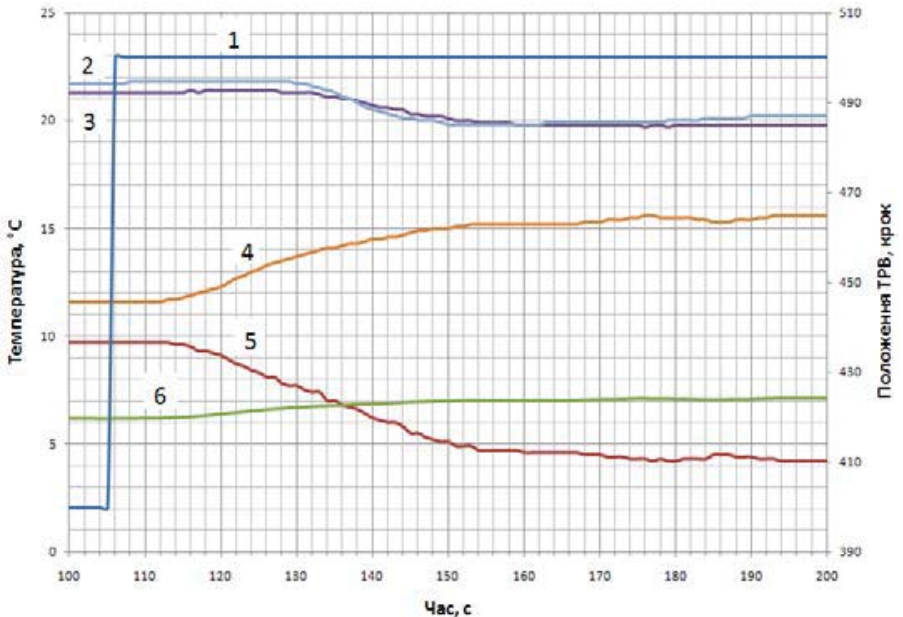

б)

Рис. 7 - Статичні характеристики ТН по каналу «Nкл - Tв.в.2» (a), та реакція ОК на ступінчасту зміну $N \kappa л$ (б).

Рис. $7 б$ демонструє реакцію ОК на ступінчасту зміну положення ЕРВ (кл) з 400 до 500 кроків. На рисунку: 1 положення ЕРВ Nкл, 2 - температура води на виході випарника Tв.в.2, 3 - температура холодоагенту на виході випарника Tф.в.2, 4 - температура холодоагенту на вході випарника Tф.в.1, 5 - температура перегріву парів холодоагенту на виході випарника $T n \phi, 6$ - тиск холодоагенту на виході випарника $P \phi . в$.

На рис. 8а представлено отримане сімейство статичних характеристик ТН як ОК по каналу «Частота обертання компресора $(N \kappa)$ - температура води на виході випарника (Tв.в.2)» при різних температурах води на вході випарника Тв.в. 1 ( 1 - Тв.в. $1=35^{\circ} \mathrm{C}, 2-$ Тв.в. $1=30^{\circ} \mathrm{C}, 3-$ Тв.в. $1=25^{\circ} \mathrm{C}, 4-$ Тв.в. $1=20^{\circ} \mathrm{C}, 5-$ Тв.в. $\left.1=15^{\circ} \mathrm{C}\right)$, та сталих витратах води через випарник $\left(G 8.6=250\right.$ л/год) і сталій температурі перегріву парів холодоагенту на виході випарника $\left(\operatorname{Tn} \phi=5^{\circ} \mathrm{C}\right)$. Представлені залежності свідчать про суттєвий вплив температури води на вході в випарник на режим його роботи. При зниженні температури води на вході випарника знижується продуктивність теплового насосу та, відповідно, його енергоефективність.

На рис. 8 представлено сімейство статичних характеристик по каналу «Частота обертання компресора (Nк) - тиск на виході випарника (Рф.в)» при різних положеннях ЕРВ $(1-N \kappa л=450$ кр., 2 - Nкл = 400 кр., $N \kappa л=350$ кр.), при сталій температурі води на вході конденсатора $\left(\right.$ Тв.к. $\left.1=30^{\circ} \mathrm{C}\right)$ та сталих витратах води крізь випарник $(\mathrm{GB} . \mathrm{B}=250$ л/год).

На рис. 8в представлена реакція ОК на зміну частоти обертання компресора з 40 об/сек до 60 об/сек. На рисунку: 1 - частота обертання компресора, 2 - температура води на виході випарника, 3 - температура фреону на виході випарника, 4 - температура фреону на вході випарника, 5 - температура кипіння фреону, 6 - перегрів фреону на виході випарника. 


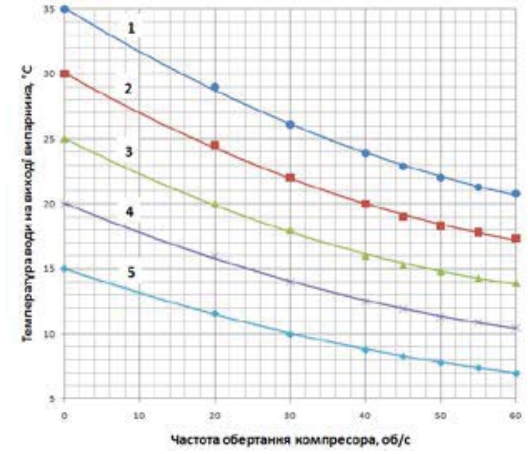

a)

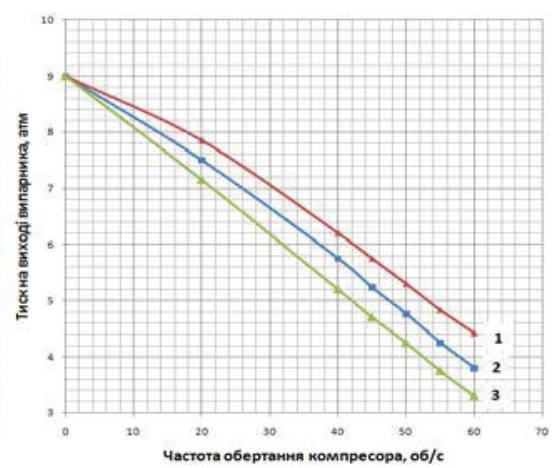

б)

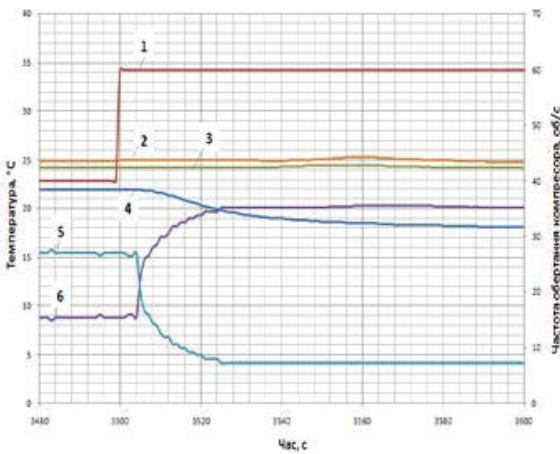

B)

Рис. 8 - Статичні характеристики ОК при зміні частоти обертання компресора (а, б) та реакція ОК на ступінчасту зміну $N \kappa$ (в)

\section{3. Дослідження системи утилізації тепла ДГ в цілому, як ОК}

Структурна схема системи УТДГ з застосуванням ТН в цілому як ОК представлена на рис. 9.

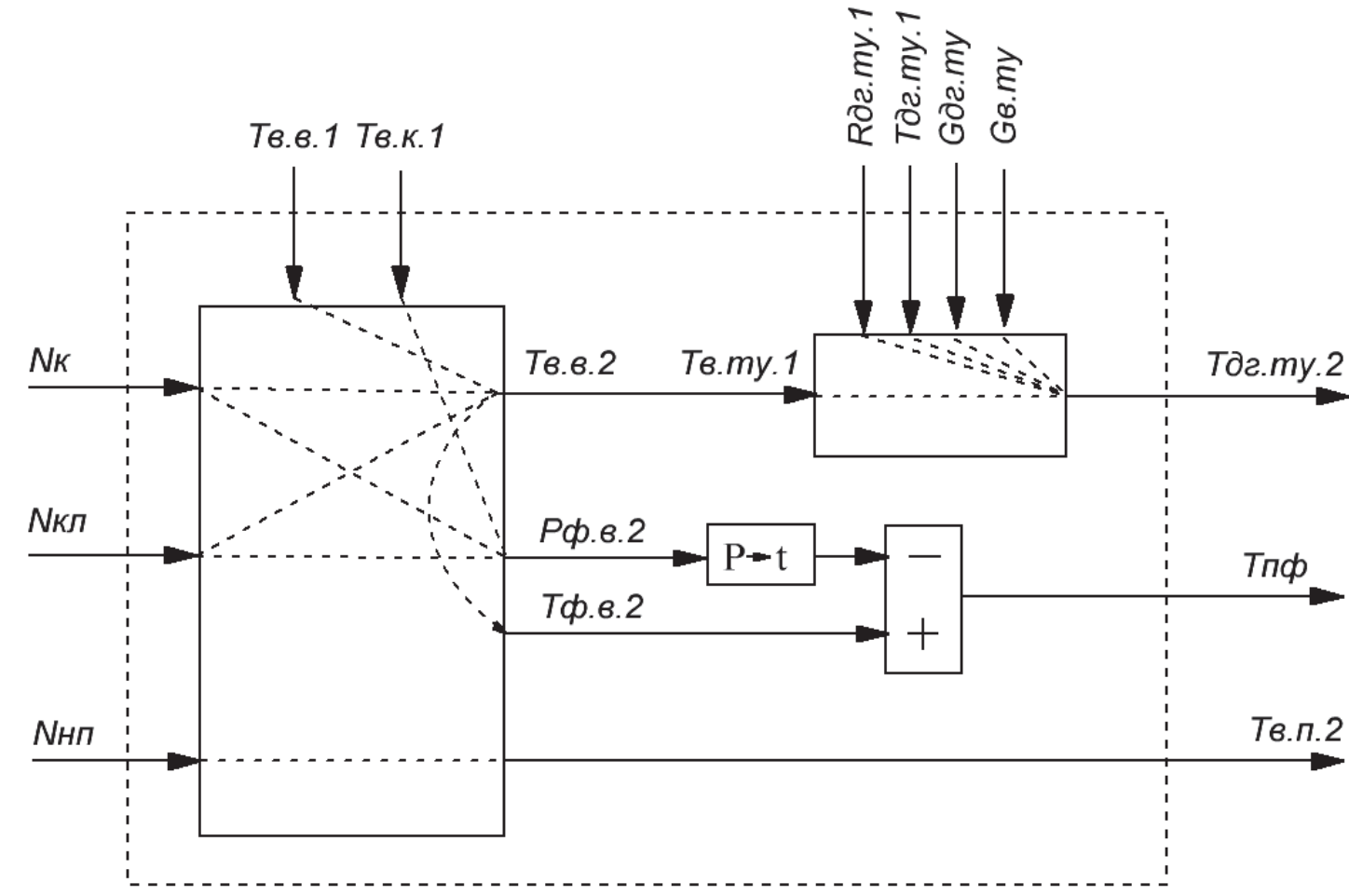

Рис. 9 - Структурна схема системи УТДГ як ОК

При дослідженні системи утилізації тепла ППС в цілому по каналу «Частота обертання компресора $N \kappa$ температура ДГ на виході ТУ Тдг.my.2» вода з виходу випарника подавалась безпосередньо до теплоутилізатора, а 3 його виходу знов до випарника. При цьому стабілізація температури води вже не відбувалась. Керуючим впливом була частота обертання компресора. Дослідження проводились при сталій температурі перегріву парів холодоагенту на виході випарника (при працюючій системі стабілізації рівня перегріву, Тпф $=5{ }^{\circ} \mathrm{C}$ ) та при сталих температурі, вологовмісту та витратах димових газів. Отримана в результаті експерименту статична характеристика по каналу «Частота обертання компресора $N \kappa$ - температура ДГ на виході ТУ Tдг.my.2» представлена на рис. 10а. Її вигляд свідчить про те, що при сталій температурі перегріву холодоагенту на виході випарника (працюючому контурі регулювання перегріву) залежність температури димових газів на виході з теплоутилізатора від частоти обертання компресора має майже лінійний характер. 


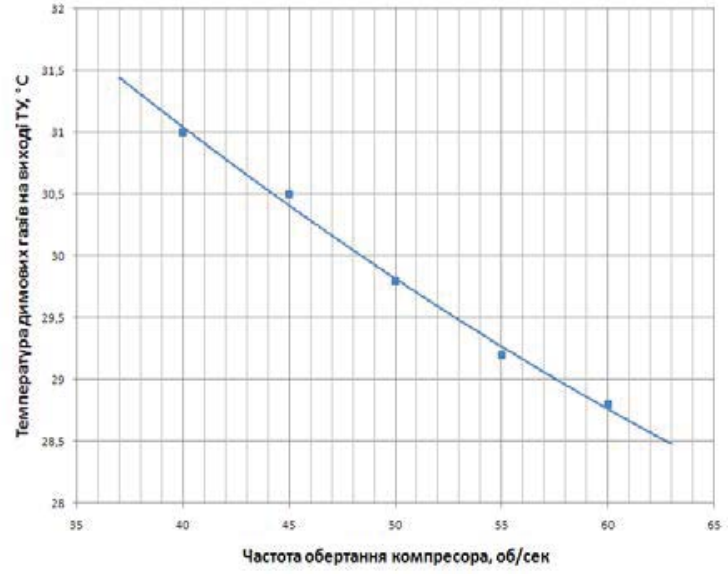

a)

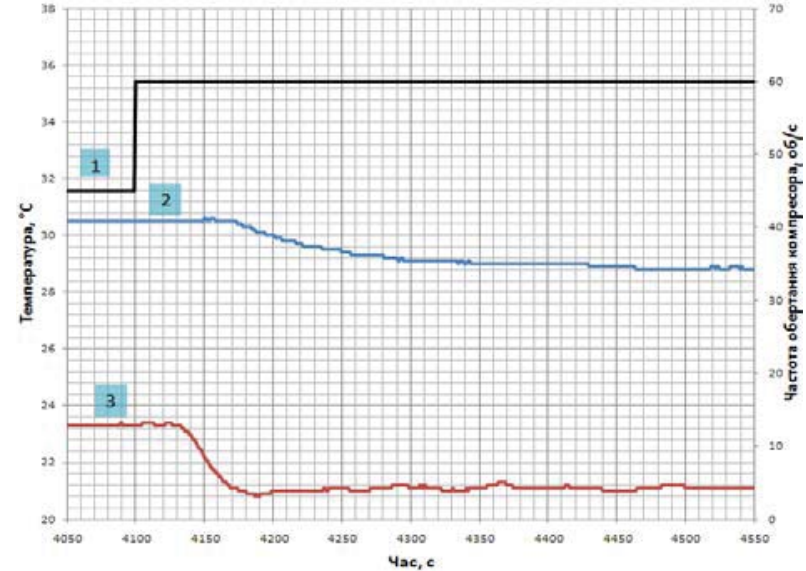

б)

Рис. 10 - Статична (а) та динамічні (б) характеристики системи УТДГ по каналу «Nk - Tдг.ту.2»

На рис $10 б$ представлена реакція системи УТДГ як ОК по каналам температури охолоджуючої води на виході випарника ТН Тв.в.2 тобто вхідної води ТУ Тв.my.1 (графік 3) та температури ДГ на виході ТУ Тдг.my.2 (графік 2) на ступінчасту зміну частоти обертання компресора $N \kappa 345$ до 60 об/с (графік 1).

3. Параметрична ідентифікація моделей каналів перетворення координатних дій процесу глибокої УТДГ як ОК

Виходячи з фізичної суті теплових процесів, що протікають в ОК, відомо, що відносно у повній мірі математично ці процеси можуть бути описані нелінійними диференційними рівняннями. Але також відомо, що номінальний режим функціонування ОК пов'язаний з порівняно вузьким діапазоном змін регульованих координат. А в такому діапазоні процеси можуть бути описані лінійними диференційними рівняннями, тобто припустимою є лінеаризація моделі ОК.

Результати експериментів підтверджують, що основні канали системи УТДГ як об'єкта керування, який відноситься до класу теплових об'єктів, мають властивість самовирівнювання, тому їх математичні моделі можуть бути описані передатними функціями першого та другого порядку наступного вигляду:

$$
W_{0}(p)=\frac{K_{0} \cdot e^{-\tau_{0} p}}{T_{0} p+1} ; \quad W_{0}(p)=\frac{K_{0} \cdot e^{-\tau_{0} p}}{\left(T_{0} p+1\right)^{2}} .
$$

Отримані експериментальні дані дозволили провести ідентифікацію моделей каналів перетворення координатних дій ОК. Для параметричної ідентифікації моделей ОК зі статичними властивостями була використана методика «двох загальних точок» [14]. Результати ідентифікації за цією методикою по каналам керуючих впливів ОК представлені в таблиці 1. В таблиці 2 представлені результати ідентифікації перехресних впливів 3 каналу на канал. В таблиці 3 представлені результати ідентифікації каналів контрольованих збурень.

Таблиця 1 - Моделі каналів керуючих впливів

\begin{tabular}{|c|c|c|}
\hline Канал & Перший порядок & Другий порядок \\
\hline $\mathrm{N}_{\text {кл }}-\mathrm{P}_{\text {ф.в }}$ & $W_{0}(p)=\frac{0,0455 \cdot e^{-9,25 p}}{18,13 p+1}$ & $W_{0}(p)=\frac{0,0455 \cdot e^{-3,7 p}}{(11,38 p+1)^{2}}$ \\
\hline $\mathrm{N}_{\text {кл }}-\mathrm{T}_{\text {ф.в.2 }}$ & $W_{0}(p)=\frac{-0,08 \cdot e^{-28 p}}{10 p+1}$ & $W_{0}(p)=\frac{-0,08 \cdot e^{-23,5 p}}{(6,88 p+1)^{2}}$ \\
\hline $\mathrm{N}_{\text {к }}-\mathrm{T}_{\text {в.в.2 }}$ & $W_{0}(p)=\frac{-0,112 \cdot e^{-24,2 p}}{16,5 p+1}$ & $W_{0}(p)=\frac{-0,112 \cdot e^{-15,05 p}}{(12,06 p+1)^{2}}$ \\
\hline $\mathrm{N}_{\text {к }}-\mathrm{T}_{\text {д.г.2 }}$ & $W_{0}(p)=\frac{-0,077 \cdot e^{-54,5 p}}{58,75 p+1}$ & $W_{0}(p)=\frac{-0,077 \cdot e^{-36,5 p}}{(36,88 p+1)^{2}}$ \\
\hline $\mathrm{N}_{\text {п }}-\mathrm{T}_{\text {в.п.2 }}$ & $W_{0}(p)=\frac{-0,135 \cdot e^{-63.2 p}}{256 p+1}$ & $W_{0}(p)=\frac{-0,077 \cdot e^{-42,5 p}}{(192.3 p+1)^{2}}$ \\
\hline
\end{tabular}


http://www.atbp.onaft.edu.ua/

Таблиця 2 - Моделі каналів перехресних звязків

\begin{tabular}{|c|c|c|}
\hline Канал & Перший порядок & Другий порядок \\
\hline $\mathrm{N}_{\text {к }}-\mathrm{P}_{\text {ф.в }}$ & $W_{0}(p)=\frac{-0,034 \cdot e^{-0,22 p}}{0,375 p+1}$ & $W_{0}(p)=\frac{-0,034 \cdot e^{-0,01 p}}{(0,275 p+1)^{2}}$ \\
\hline $\mathrm{N}_{\text {кл }}-\mathrm{T}_{\text {в.в.2 }}$ & $W_{0}(p)=\frac{-0,08 \cdot e^{-23 p}}{8 p+1}$ & $W_{0}(p)=\frac{-0,08 \cdot e^{-18 p}}{(5.8 p+1)^{2}}$ \\
\hline
\end{tabular}

Таблиця 3. Моделі каналів контрольованих збурень

\begin{tabular}{|c|c|c|}
\hline Канал & Перший порядок & Другий порядок \\
\hline $\mathrm{T}_{\text {в.в.1 }}-\mathrm{T}_{\text {в.в.2. }}$ & $W_{0}(p)=\frac{1 \cdot e^{-10.2 p}}{18.1 p+1}$ & $W_{0}(p)=\frac{1 \cdot e^{-7.1 p}}{(14.2 p+1)^{2}}$ \\
\hline $\mathrm{T}_{\text {в.к.1 }}-\mathrm{P}_{\text {ф.в }}$ & $W_{0}(p)=\frac{0,16 \cdot e^{-12.5 p}}{25.1 p+1}$ & $W_{0}(p)=\frac{0,16 \cdot e^{-6.2 p}}{(15.3 p+1)^{2}}$ \\
\hline
\end{tabular}

Представлені у таблиці передатні функції адекватно описують лише динамічні властивості об’єкта, тому що їх статичні характеристики є досить складними функціями декількох змінних. Так, наприклад, тиск холодоагенту на виході випарника (Рф.в.2) і температура води на виході випарника (Тв.в.2) є функціями мінімум трьох змінних положення ЕРВ, частоти обертання компресора та температури води на вході в конденсатор, при цьому залежності температури води на виході випарника від частоти обертання компресора і температури води на вході випарника $є$ суттєво нелінійні.

\section{4. Висновки.}

В результаті проведених досліджень отримані експериментальні залежності по основним каналам перетворення координатних дій процесу УТДГ. Проведена структурна ідентифікація процесів в контактномому теплоутилізаторі, тепловому насосі та УТДГ в цілому. Складена структурна схема процесу як ОК. Проведено параметричну ідентифікацію та отримані математичні моделі основних каналів

Отримані результати свідчать про наявність досить сильних перехресних впливів керуючих дій та збурень в результаті того що статичні характеристики основних каналів УТДГ як ОК є досить складними функціями декількох змінних.

\section{Список використаних джерел}

[1] Тюрин М. П. и др. Эффективные типовые устройства для утилизации теплоты от теплотехнологического оборудования / М.П. Тюрин //Успехи в химии и химической технологии. - 2010. - Т. 24. - №. 1 (106).

[2] Сухоцкий А. Б. Вторичные энергетические ресурсы. - 2014.

[3] Ковальчук Д. А. Оценка энергетической эффективности газового конденсационного водогрейного котла как объекта управления / Д.А. Ковальчук, О.В. Мазур, С.С. Гудзь // Наукові праці ОНАХТ. - 2017. - Т. 80. - №. 2.

[4] Жовмір М.М. Утилізація низькотемпературної теплоти продуктів згорання палив за допомогою теплових насосів / М.М. Жовмір // Промышленная теплотехника. — 2008. — Т. 30, № 2. — С. 90-98. — Бібліогр.: 10 назв. - укр.

[5] Использование теплоты конденсата «глухого» пара и теплоты паровоздушной смеси [Електронний ресурс] Режим доступу до ресурсу: http://studbooks.net/1897332/

[6] Ефимов А. В. Система глубокой утилизации теплоты газов, уходящих из котельных агрегатов / А.В. Ефимов, А.Л. Гончаренко, А.В. Гончаренко// - 2013.

[7] Kovalchuk D., Mazur A., Hudz S. The model for power efficiency assessment of condensation heating installations //Автоматизація технологічних та бізнес-процесів. - 2017. - Т. 9. - №. 3.

[8] Ротов П. В. и др. Повышение эффективности работы централизованных систем теплоснабжения за счет применения теплонасосных установок //Промышленная энергетика. - 2014. - №. 7. - С. $27-31$.

[9] Чепурний М. М., Резидент Н. В. Використання теплоти відхідних продуктів згорання палива в теплонасосних установках. - 2013.

[10] Солодкая А. В. Изучение процессов теплопереноса в теплообменнике с гранулированной насадкой //Scientific Works. - 2016. - Т. 80. - №. 2.

[11] Петрикеева Н. А. и др. Использование полной теплоты сгорания топлива в котельных установках //Научный журнал. Инженерные системы и сооружения. - 2014. - Т. 2. - №. 4. - С. 76. 
[12] Клименко В. Н. Некоторые особенности применения парокомпрессионых тепловых насосов для утилизации сбросной теплоты отопительных котлов //Промышленная теплотехника. - 2011.

[13] Ковальчук Д. А. Дослідження процесів утилізації тепла пароповітряних сумішей: лабораторна установка, вимірювані змінні, автоматизація експериментів / Д.А. Ковальчук, О.В. Мазур, С.С. Гудзь //Automation of technological and business processes. - 2018. - Т. 10. - №. 2.

[14] Хобин В. А. Системы гарантирующего управления технологическими агрегатами: основы теории, практика применения //Одесса: ТЕС. - 2008. - Т. 306.

[15] Жук А. Ю. Адаптивные системы управления //Молодежный научно-технический вестник. - 2013. - №. 5. - С. 24-24.

[16] Ибраев А. М. и др. Анализ энергетических потерь парокомпрессионной холодильной машины, связанных с процессом перегрева рабочего тела в испарителе //Вестник Казанского технологического университета. - 2013. - T. 16. - №. 21.

[17] Петраков Г. Н. Повышение эффективности работы теплового насоса в системах теплоснабжения за счет модернизации конденсатора : дис. канд. техн. наук : 05.14.04 / Петраков Г. Н. - Воронеж, 2006. - 206 с.

\section{References}

[1] Tyurin M. P. et al, Effektivnyie tipovyie ustroystva dlya utilizatsii teplotyi ot teplotehnologicheskogo oborudovaniya, Uspehi v himii i himicheskoy tehnologii, vol. 24, no. 1, p. 106, 2010.

[2] A. B. Suhotskiy, Vtorichnyie energeticheskie resursyi, 2014.

[3] D.A. Kovalchuk, A. V. Mazur, S. S. Hudz, Otsenka energeticheskoy effektivnosti gazovogo kondensatsionnogo vodogreynogo kotla kak ob'ekta upravleniya, Naukovi pratsi ONAHT, vol. 80, no. 2, 2017.

[4] ZhovmIr M.M., UtilIzatsIya nizkotemperaturnoyi teploti produktiv zgorannya paliv za dopomogoyu teplovih nasosIv, Promyishlennaya teplotehnika, vol. 30, no. 2, pp. 90-98, 2008.

[5] Ispolzovanie teplotyi kondensata «gluhogo» para i teplotyi parovozdushnoy smesi [Online]. Available at: http://studbooks.net/1897332/

[6] A. V. Efimov, A. L. Goncharenko, Sistema glubokoy utilizatsii teplotyi gazov, uhodyaschih iz kotelnyih agregatov, 2013.

[7] D. A. Kovalchuk, A. V. Mazur, S. S. Hudz, The model for power efficiency assessment of condensation heating installations, AvtomatizatsIya tehnologIchnih ta bIznes-protsesIv, vol. 9, no. 3, 2017

[8] P. V Rotov et al, Povyishenie effektivnosti rabotyi tsentralizovannyih sistem teplosnabzheniya za schet primeneniya teplonasosnyih ustanovok, Promyishlennaya energetika, no. 7, pp. 27-31, 2014.

[9] M.M. Chepurniy, N.V Rezident. Vikoristannya teploti vIdhIdnih produktIv zgorannya paliva $v$ teplonasosnih ustanovkah, 2013.

[10] A. V. Solodkaya, Izuchenie protsessov teploperenosa v teploobmennike s granulirovannoy nasadkoy, Scientific Works, vol. 80, no. 2, 2016.

[11] N. A. Petrikeeva et al, Ispolzovanie polnoy teplotyi sgoraniya topliva v kotelnyih ustanovkah, Nauchnyiy zhurnal. Inzhenernyie sistemyi i sooruzheniya, vol. 2, no. 4, p. 76, 2014.

[12] V. N. Klimenko, Nekotoryie osobennosti primeneniya parokompressionyih teplovyih nasosov dlya utilizatsii sbrosnoy teplotyi otopitelnyih kotlov, Promyishlennaya teplotehnika, 2011.

[13] D. A. Kovalchuk, A. V. Mazur, S. S. Hudz, DoslIdzhennya protsesIv utilIzatsIYi tepla paropovItryanih sumIshey: laboratorna ustanovka, vimIryuvanI zmInnI, avtomatizatsIya eksperimentIv, Automation of technological and business processes, vol. 10, no. 2, 2018.

[14] V. A. Hobin, Sistemyi garantiruyuschego upravleniya tehnologicheskimi agregatami: osnovyi teorii, praktika primeneniya, Odessa: TES, vol. 306, 2008.

[15] A. Yu. Zhuk, Adaptivnyie sistemyi upravleniya, Molodezhnyiy nauchno-tehnicheskiy vestnik, no. 5, p. 24-24, 2013.

[16] A. M.Ibraev et al, Analiz energeticheskih poter parokompressionnoy holodilnoy mashinyi, svyazannyih s protsessom peregreva rabochego tela $v$ isparitele, Vestnik Kazanskogo tehnologicheskogo universiteta, vol. 16, no. $21,2013$.

[17] G. N. Petrakov, Povyishenie effektivnosti rabotyi teplovogo nasosa $v$ sistemah teplosnabzheniya za schet modernizatsii kondensatora. dis. kand. tehn. nauk : 05.14.04. - Voronezh, 2006. 